\title{
Are Public Sector Tax Practitioners Satisfied with the Services of South Africa Revenue Service?
}

UDK: 35:336.22(045)

\author{
Oludele Akinloye Akinboade \\ economist_oa@yahoo.com \\ Mandisa Putuma Mokwena \\ mandisa.mokwena@gmail.com
}

\section{ABSTRACT}

The paper discusses the satisfaction with services provided by South Africa Revenue Service (SARS) to public sector tax practitioners to enhance tax compliance. A survey of 375 tax practitioners in eight provinces was made. Tax practitioners appreciate SARS services in paying tax refunds, responding to and handling enquiries, tax practitioners education and the organization of professional training/workshops. Accountants in particular strongly appreciate SARS tax practitioners education. Accountants and older tax practitioners appreciate SARS assistance in completing tax returns. Tax practitioners who work as Financial Managers, Accountants, and those who possess secondary level of education, diploma, degree or have special tax education find tax payer training to be quite useful. Older tax practitioners are more satisfied with SARS office services.

Key words: tax compliance, tax practitioners, service satisfaction, tax administration, South Africa

JEL: D73, H26, M48, H83, L84

\section{Introduction}

Tax noncompliance is a phenomenon confronting income tax administration across the globe. Recent reports indicate that tax practitioners in South Africa might be having tax compliance challenges. Tax noncompliance is defined as taxpayer's failure to remit a proper amount of tax. This could be attributed to the complexity or even contradictions in the tax legislation or tax administration procedure (Jackson \& Milliron, 1986, p. 136; Kesselman, 1994; Kasipillai \& Jabbar, 2003, p. 2). Noncompliance is also perceived as the failure of a taxpayer to report (correctly) the actual income, claim deductions 
and rebates and remit the actual amount of tax payable to the tax authority on time (Kirchler, 2007, p. 3).

Government departments in South Africa face challenges in the collection, storage and dissemination of tax revenue information. Most of these departments could sometimes only rely on manual file based taxation information storage with hardly any dissemination taking place. Tax practitioners employed in public sector bodies, such as Chief Financial Officers, Finance Managers, Finance Officers, Accounting Officers etc., assist government departments to meet their tax payment obligations. Tax practitioners also are beginning to perform more technical duties, such as implementing, controlling, and auditing computer systems and networks and developing a business's technology plans. With the aid of special software packages, tax practitioners summarize transactions in the standard formats of financial records and organize data in special formats employed in financial analysis. A growing number of tax practitioners with extensive computer skills also specialize in correcting problems with software or in developing software to meet unique data management and analytical needs.

Unfortunately, in South Africa no minimum standard exists in respect of qualifications or experience required for tax practitioners to engage in the profession and that not all tax practitioners are subject to a code of professional conduct. Only about 55\% of tax practitioners registered with SARS are registered with any professional body while others have no oversight or accountability (Lee, 2012).

The relationship between the tax agency and tax advisers could be viewed from an individualist perspective whereby they pursue mutually inconsistent objectives in an adversarial relationship. Some authors opine tax payments are commonly associated with emotions such as hope, despair, anger, outrage, defiance, frustration, disdain, suspicion, and deference (Rawlings \& Braithwaite, 2003, p. 263). While the state is pursuing a goal of revenue maximisation, the ethical obligation of tax advisers is to uphold the law by ensuring that their client pays no more tax than is required by law(Burton \& Dabner, 2008, p. 109).

The second view of the relationship flows from Rousseau's (1762) concept of the "general will" whereby the individual and the state are not a dichotomy but a unity framed upon a common identity. The tax agency and the tax practitioners could be seen as comprising a partnership which pursues fulfilment of the "general will" expressed in the community's tax laws. Such a partnership may experience friction, but the parties strive to minimise conflict and seek to achieve negotiated positions and "practical« outcomes consistent with the "general will« (Burton \& Dabner, 2008, p. 110). In this context, Tax agencies need processes that do not just make it easy for citizens to understand their obligations and comply with the rules, but also make it difficult for them not to comply. Above all, systems must be flexible enough 
to allow prevention and detection strategies and business rules to change regularly, so that agencies are not outmanoeuvred by the constantly evolving tactics of tax evaders (Pretty \& Negadi, 2012).

As an example, the Australia Tax Office (ATO) has changed the manner of its dealings with tax practitioners. This paradigm shift includes changes to the type of information it gathers, the preparedness to publicly disseminate information relevant to both taxpayer compliance and the accountability of the ATO, the breadth of its consultative arrangements with tax advisers and also its efforts to ease the administrative burden of tax advisers (Burton \& Dabner, 2008, p. 111)

The recent trend towards the use of public private partnerships (PPP) to provide services traditionally carried out by the public sector alone, makes it imperative for SARS to also make a paradigm shift in its relationship with tax practitioners. The PPP arrangement has given rise to a number of value added tax (VAT) compliance issues of which the public sector partner needs to be aware and where SARS education programme will be of crucial importance. The public sector partner has to determine the nature of the service being provided, the person providing the service, the VAT treatment of the income and the person responsible for declaring the VAT and deducting VAT on any related costs (Deloitte, 2006).

Although many VAT compliance issues are common to all public sector bodies, those operating in different sectors will encounter issues that are specific to them. For example, any public sector body, running retail outlets, granting concessions for retail outlets, operating staff canteens, providing parking facilities, or providing general sporting or entertainment amenities for the community should consider whether they are required to be accounting for VAT (Deloitte, 2006). Local authorities will also be required to account for VAT in respect of fees obtained from the provision of golfing facilities, among others. Government departments may provide computer and internet services to employees. These may not be taxable if the services are required to carry out government business obligations, but a tax liability will exist if an employer-funded computer is purchased by the employee for personal use.

Published research concerning tax advisor's compliance behaviour in general and in South Africa in particular is still very limited. Nienaber (2010, pp. 33-37) reviews the literature on factors that could influence the ethical behaviour of tax professionals in South Africa. Hazelhurst (2003, p. 64) suggests that the difficult tax legislation implemented and ineffective tax collection pre-1994 have allowed South African taxpayers to divert large amounts of income tax to tax shelters and tax havens.

This paper is organised as follows: section one is essentially introductory. It discusses background issues of the connection between tax compliance and taxation issues of relevance to public sector bodies, the SARS and the manner 
of interacting with tax practitioners. Section two highlights the role of tax practitioners in tax compliance in general and links this discussion to the expanded taxpayer service programme of revenue agencies where there is a paradigm shift in terms of the understanding of tax authorities relationship with the taxpayer and tax practitioners in particular. This leads to a discussion of what constitutes service satisfaction especially as it relates to a public body discharging services to tax paying customers. The study research methods are the focus of discussion in section three while results of the study are presented in the fourth section. The last section concludes the paper.

\subsection{The Problem Statement}

In South Africa, the state lost R300 million (US\$ 36.6 million) through fraud and other financial misconduct by civil servants in the 2009/10 financial year, according to the Public Service and Administration Minister Lindiwe Sisulu. R260 million (US\$ 31.7 million) was lost in national departments and R40 million (US\$ 8.88 million) in provincial departments (Fin24, 2012). An analysis of compliance among South Africa's 35,000 tax advisors shows that, in their personal capacity, they are indebted to SARS to the tune of R260 million (US\$ 31.7 million), whilst at the same time they have 18,000 outstanding returns (Lee, 2012). Non-compliance by trusts and companies is also a key area of concern for SARS, and it has been determined that tax practitioners could be linked to over 107,600 companies and trusts.

Problems relating to physical mobility make it difficult for tax agencies to correctly assess liabilities or track taxpayers. Then there is the availability of public sector online channels that is making it easier and cheaper for criminals to target tax agencies from anywhere in the world (Pretty \& Negadi, 2012). Hence, Lederman (2007, p. 695) suggests that one way in which tax administrators can ease enforcement difficulties is by using third parties as verifiers. Structurally, third parties have the incentive to verify the bona fides of the taxpayers' claim so that they do play an educational role. Tax practitioners can slow down or eliminate non-compliance resulting in reduced or little enforcement costs to taxpayers. However, where tax advisors engage in or encourage non-compliance, government needs to address these situations through legislation or monitor closely the audit process. People need a minimum fiscal knowledge to practice tax avoidance. Otherwise, they can use tax practitioners as paid assistance to devise strategies to exploit legal ambiguities. On the other hand it could be argued that experts reduce compliance costs by reducing legal uncertainties (Beck et al. 1994; Scotchmer 1989, p.182) and time or even anxiety costs (Reinganum \& Wilde, 1991).

There have been many complaints regarding substandard service delivery by tax practitioners to their clients in respect of advice and tax compliance representation (SARS, 2003, p. 2). The complaints generally centre on the manner in which tax returns are completed. Tax returns are completed on the advice of the tax consultant or advisor who bears limited responsibility 
for the advice given (SARS, 2003, p.2). While individuals can deliberately omit to report income, non-payment can also be due to errors, especially administrative errors within the tax organisation or submission of inaccurate information without the declaring taxpayer being aware. A lack of good quality data and poor data management combine to prevent tax preparing agencies gaining a clear picture of who is paying what, who is not, and what they should be paying (Pretty \& Negadi, 2012).

Smaller tax practitioners in many developing countries may not have the infrastructure of more established tax practitioners. They may be at a disadvantage when it comes to identifying and recording certain taxable line items and hence may risk being non-compliant personally or making their clients non-compliant. Self-employed Chartered Accountants (CAs) or those employed in smaller private and public sector organizations must be vigilant in the proper identification and recording of taxable items in order to increase compliance with SARS guidelines.

From the perspective of SARS, this means a great deal of time and energy is spent unnecessarily and inefficiently in correcting errors made by or addressing the unprofessional conduct of a small but significant number of tax practitioners. It is hence of immense importance that a number of common practices in public sector organizations that qualify as taxable items would be identified and reported.

SARS has embraced this notion of responsive regulation and is reaching out to taxpayers, emphasizing education, good customer service, and an open dialogue. SARS hence targets South Africa's tax practitioners' sense of social responsibility and bolsters the prevention of noncompliance, while avoiding, at least early in the regulatory interaction, the use of costly punitive measures that might undermine tax practitioners' goodwill and intrinsic motivations to comply.

Experts advised that SARS could benefit greatly from conducting a study of this taxpayer group as a means to attain the required greater understanding of key segments. This has prompted the introduction of new legislation and a paradigm shift by SARS in terms of how the organisation relates to tax practitioners and the need to embrace the profession by providing comprehensive services to them. This can form the basis of a strategy to address key segments with appropriate communication and channel strategies to facilitate even more efficient tax collection. This informed the conduct of a survey of the needs of private sector tax practitioners in the country. 


\subsection{Taxation issues of relevance to public sector bodies}

The public sector is not totally immune from tax. Like other organizations that provide services, own and manage assets, buy products and employ people, those in the public sector have tax costs to manage and obligations to meet.

Goods and services supplied by public sector bodies, governments however are not subjected to full value added taxation. Gendron (2005) discusses the output of the public sector bodies as consisting of a combination of goods and services, is often treated as final consumption by the organization itself rather than consumption by the ultimate final consumers (persons).

For tax purposes, goods and services supplied by the public sector fall into the four categories:

Taxable. Any supply to which the tax applies at the normal rate is taxable. The seller is entitled to a refund of value added tax (VAT) incurred on input purchases undertaken to make taxable supplies.

Zero-rated. Any supply to which the tax applies at a rate of zero percent is said to be zero-rated. Even though the seller does not collect VAT on such supplies, it is entitled to a refund of the VAT incurred on input purchases undertaken to make zero-rated supplies.

Under a destination-based VAT system, any exported supplies are zero-rated.

Exempt. The seller does not collect the tax when making an exempt supply. Unlike the zero-rated case, however, the seller is not entitled to a refund of the VAT incurred on input purchases undertaken to make exempt supplies.

Non-taxable. Such activities are outside the scope of the VAT. Similar to the exempt case, the seller is not entitled to a refund of the VAT incurred on input purchases undertaken to make non-taxable supplies. This terminology is used in the European Union (EU) only and originates from the Sixth VAT Directive. The economic effects of the non-taxable status are the same as the exempt status. The distinction arises in the EU because the Sixth Directive identifies certain activities as specifically exempt.

Countries such as Australia, Canada, and New Zealand, as well as jurisdictions such as the Province of Quebec (Canada) use the taxable, zero-rated, and exempt categories. In Australia, sales are said to be taxable, GST-free, and input taxed, respectively. In New Zealand, zero-rated supplies are called non-taxable supplies. A significant proportion of supplies made by the public sector are exempt. Various VAT refund schemes that apply to input tax incurred on supplies other than taxable ones.

Taxation of public sector employees varies from country to country. For example, public sector employees are exempt from income tax in Sri Lanka but not in neighbouring India. Burmese authorities began to impose income tax on civil servants and military personnel from August 2006 (Paung, 2006). 
In many countries and instances, special tax rules apply to government run entities. In some countries (e.g., in Germany, Italy, and Austria), civil servants are fully or partly exempt from social security taxes (old-age income, unemployment, or health insurance; see, e.g., Cardona, 2002). To the extent to which it relies on civil servants as its personnel, the government enjoys a labour cost advantage over the private sector.

In many countries, public-sector pension plans are extensively regulated by the country's Internal Revenue Code (IRC), the common source of rules governing the deferral of taxation for each type of pension plan. Because of their well-developed benefit programmes, the significant size of assets, and their large numbers of active and retired members, public-sector pension plans are naturally the subject of interest to all stakeholders involved in their operation, including public employers; employer associations; plan members and employee organizations; taxpayers; legislators on the state, local, and federal level; and, last but not least, beneficiaries (Employee Benefits Research Institute, 2005).

Civil servants in South Africa used to enjoy huge benefits and were showered with perks such as tax exemptions and preferential treatment on home loans. Things have however changed. From February 1998, lump sums payable on retirement by a state pension fund were no longer tax-free (Business Times, 1998).

Under the South African tax system, the financial savings in some instruments are broadly provided three types of tax incentives, viz., (a) deductions, (b) exemptions and (c) tax rebates. Tax incentives on financial instruments having short and medium term lock-in provisions are evidenced to be used more as a vehicle for tax avoidance, by recycling of existing savings, than as an instrument for financial accumulation. In contrast, the saving in financial instruments with long lock-in provisions is generally undertaken with an objective to smoothing future consumption, in the events of anticipated fall in earned income (particularly retirement), anticipated increase in consumption needs (such as children) as well as unpredictable increase in needs and unpredicted reduction in income.

Different financial instruments could be categorized into (a) long-term financial savings, i.e., savings in financial assets having, say, more than 6 years of maturity and (b) short and medium-term financial savings, i.e., savings in financial assets having up to 6 years of maturity. The major financial instruments forming part of long-term savings particularly for old age security are Employees Provident Fund, Public Provident Fund, Public Pension Fund, etc., while financial instruments with short and medium-term redemption period include deposits, Government securities, relief bonds, national savings certificate, national saving scheme etc. While old age security schemes are meant to be illiquid and are not marketable instruments, financial instruments in securities like bonds and debentures, shares and government securities 
should technically be treated as short to medium-term savings for tax purposes because of their high liquidity and marketability (Kumar, no date).

\subsection{Tax non-compliance in public sector bodies}

Throughout all levels of government, tax and revenue agencies responsible for collecting government revenues are under pressure to produce more with fewer resources. Tax compliance reputation is critical for government and public sector bodies. It is embarrassing to public sector organisations when administrative errors of tax preparers or submission of inaccurate information leads to inaccurate assessment of officials tax liabilities. A 2012 report from the United States Internal Revenue Service (IRS) reveals that 36 of President Obama's executive office staff owe the country US\$ 833,970 in back taxes (Malcom, 2012). The IRS' 2010 delinquent tax revelations finds that officials of the U.S. Senate, House of Representatives, Department of Education, Homeland Security, Active duty military members owe US\$2.1 million, US\$ 8.5 million, US\$ 4.3 million, US\$ 37 million and more than US\$ 100 million respectively.

The Postal Service, Veterans Affairs, Department of Energy, Department of Justice, owe almost US\$270 million, US\$151 million, US\$ 5 million, and nearly $\$ 17$ million in back taxes respectively. There were 8,000 cases of noncompliance among IRS employees. Tim Geithner, had to pay up US\$ 42,000 in his own back taxes before being confirmed as US Treasury Secretary. The same Department had 1,181 other employees with delinquent taxes totalling US\$ 9.3 million.

While many public agencies in Europe have already established processes for compliance and enforcement, a combination of tax avoidance and error is still costing hundreds of billions of Euros in lost revenues for citizens every year. Tax preparers have to be familiar with the latest tax avoidance schemes.

In France in 2010 the tax and customs offices, DGFIP, reported a 3.5\% increase in detected fraud, equivalent to $€ 97$ million, bringing the total amount of revenue lost to fraud to $€ 2.8$ billion. In the United Kingdom this year, tax avoidance schemes operated by big companies are described by the UK treasury as »aggressive» and »highly abusive« tax shelters.

In the United Kingdom, there are problems of public sector employees being paid off the public sector payroll, and instead being paid through a contract with their own personal service company. Data are available for civil service $(2,400)$ and the BBC (about 25,000). Pay As You Earn is at the very heart of this issue and the corresponding lack of deduction for National insurance costs the government $€ 106$ billion in 2012. Government deficit will grow as long as this abuse is not stopped (Murphy, 2012). Annual Fraud Indicator has put the loss to the UK economy from fraud at $€ 73$ billion (NFA, 2012). 
The health sector and tax authorities are the masters in corruption in Greece. Greece's public administration inspector's report for 2011 finds that out of 1,403 corruption cases examined, the worst offenders were officials working at the tax authority as well as high ranking civil servants with many years of work experience (Rakitzis, 2012). The majority of corruption cases concern local government officials, and employees in the health sector, at social security funds and town planning offices. Civil servants continue to establish their own private »businesses" within the public services knowing they won't get punished.

\subsection{Objective of the study}

The principal objective of this study is to examine the public sector tax practitioners opinion of services received from SARS and compare them to those received from other tax advisors, intended to improve tax compliance, and the degree to which they are satisfied with them. Also, the study examines tax practitioners satisfaction with general services provided by SARS.

\section{The role of tax practitioners in tax compliance}

The term »tax practitioner covers a diverse group of individuals, business structures and professional groups who provide a range of tax services for their clients. Self-employed and in-house accountants, tax advisers and registered tax agents, tax agent franchises and legal practitioners in the tax area are all embraced by the term (Marshall et al, 2006).

Westat (1980) reports that tax preparers believe their clients think of them as advocates. Consequently, if one assumes preparers are meeting the demands of their clients, the tax professional is an agent for the taxpayer. A competing view is that of the tax professional is an agent of tax administration, though this is a position sometimes put forth by the IRS (and weakly promoted through the use of preparer penalties), it does not appear to have support $m$ the tax practitioner community. They are the channel of communication between SARS and large business taxpayers, particularly public bodies employing large numbers of taxpayers.

Hence, the role and behaviour of tax preparers in the tax system is very important. Roth et al, (1989) suggest that one of the most important influences on compliance behaviour is the community of tax practitioners. Professional tax advisors make compliance decisions either for, or in conjunction with, their clients. Tomasic and Pentony (1991) put the roles of tax practitioners into six categories, viz: acting (1) as independent advisers of their clients, (2) as unpaid employees of the internal revenue office, (3) as intermediaries between the internal revenue office and the taxpayer, (4) as tax advisers, (5) as protectors of their practice and finally as influences on the systems. Importantly Tomasic and Pentony (1991) concluded that tax practitioners play a major role in increasing the level of taxpayer compliance. Boccabella 
(1993, p.391) also identifies a range of additional broad tasks that tax practitioners may currently be required to perform. These functions include representing and negotiating on behalf of taxpayers in proceedings with both the revenue authorities and policy makers.

Public sector bodies are expected to enforce the submission of valid tax clearance certificates in their public procurement and tender processes. South Africa Revenue Service can request details of payments made for any purpose by government departments and statutory bodies. Such information is usually required to assist in the selection of cases for audit and is normally related to payments made to specific persons or classes of persons. As an example, information could be requested from government departments in relation to grants, subsidies and contract payments for use in SARS audit operations.

Taxpayers are generally ambivalent about the morality of tax cheating. This increases the pressure on tax practitioners (Song \& Yarbrough, 1978, p. 442). Someone who provides aggressive tactic might interpret and present facts that lead to different tax liabilities. This type of advice could lead clients to adopt tax positions that would probably not be upheld in a SARS audit. This is risky on account of the possibility that such an audit could result in legal disputes ((Hite \& McGill, 1992, p. 400). Successful audits result in a penalty that even reduces client's »good « (Kaplan et al. 1988, p. 426). The loss of such good has a substantial influence on tax agents' reputation. Ayres, Jackson and Hite (1986, p. 300) study factors that explain differences in tax professionals' decisions in "gray" tax areas. They find that taking the effect on costs and benefits into account, as suggested by the individual tax compliance literature, the most obvious alternative is that Certified Public Accountants (CPAs) make best-effort normative evaluations. Experiences with tax administrations might influence their behaviour. With more experience, tax agents will obtain a higher knowledge on how to deal with tax administrations (Kaplan et al. 1988, p. 430).

Sakurai and Braithwaite (2001) show that tax practitioners (taxpayers) are quite successful in finding their suitable client (рractitioner). They observe a specific market segmentation. Taxpayers who intend to minimise their taxes and who are high risk takers find tax agents who are good at finding loopholes. On the other hand, risk averse taxpayers find tax agents who fit in their demand.

Klepper and Nagin (1989, p. 167) also investigated the role of the tax practitioner in preparing tax returns. Similarly, Klepper, Mazuar and Nagin (1991, p. 205) develop an econometric model to empirically test the influence of tax preparers upon the compliance behaviour of taxpayers. They find that an expert's participation will discourage non-compliance on legally unambiguous income sources but encourage non-compliance on ambiguous 
sources. The size of the enforcer/ambiguity-exploiter influence will be directly related to the quality of the evasion opportunity.

Erard (1993) finds that the use of tax practitioners, particularly CPA's and tax lawyers is associated with increased levels of non-compliance. In particular, substantial differences in compliance characteristics is reported amongst the three categories of tax preparers (CPA and Lawyer, Non-CPA and Lawyer and self-prepared). The non-compliance on returns prepared by CPA and lawyers tends to be larger in frequency, average level, and variance as opposed to the returns from the other two categories.

\subsection{Taxpayer expanded service paradigm of Revenue Authorities}

Evans and Lindsay (2001) identify three basic components of services, viz: the physical facilities, the processes and the procedures. The employees' behaviour typifies service processes while employees' professional judgments make up service procedures. A combination of process change and technology evolution is evident in the most effective tax agencies. Their systems and processes have already been modernised to maximise yield by improving compliance (Pretty and Negadi, 2012). Recently, many internal revenue authorities have been shifting from the traditional »enforcement« paradigm often used to analyze tax compliance behaviour, in which taxpayers are viewed and treated as potential criminals, and the emphasis is on repression of illegal behaviour through frequent audits and stiff penalties (Allingham \& Sandmo, 1972, p. 335). An expanded «service« paradigm is now being embraced which recognizes the role of enforcement, but also emphasizes the role of tax administration as a facilitator and a provider of services to taxpayer-citizens. This has had significantly positive effects on citizen perception of the tax administration.

Customer focus is now being emphasized as an important theme in public management (Williams, Saunders \& Staughton, 1999; Alford, 2002, p. 337); and in recent years public organizations have been striving to enhance services to customers (Klein, 2001, p. 41; Giannoccaro, Costantino, Ludovico \& Pietroforte, 2008, p. 3). For example, there has been pressure on the public sector to offer more government services (Lau, 2000), and governments in different parts of the world compete among themselves by launching new initiatives to improve services to their citizens (Jakka, 2004, p. 239).

SARS has embraced this notion of responsive regulation and is reaching out to taxpayers, emphasizing education, good customer service, and an open dialogue. SARS hence targets South Africa's tax practitioners' sense of social responsibility and bolsters the prevention of noncompliance, while avoiding, at least early in the regulatory interaction, the use of costly punitive measures that might undermine tax practitioners' goodwill and intrinsic motivations to comply. 
Fox and Meyers (1995, p. 118) define service delivery as the provision of public activities, benefits or satisfactions to the citizens. Service delivery relates both to the provision of tangible public goods and intangible services. This can be done by government institutions, organisations, private companies, non profit organisations and individual service providers. Table 1 provides an example of services provided by revenue authorities across the world.

Table 1: Revenue Agencies Service Categories

\begin{tabular}{|c|c|c|c|}
\hline Service category & Description & Examples of services & Characteristics \\
\hline Information & $\begin{array}{l}\text { Information services } \\
\text { and products } \\
\text { which are one way } \\
\text { communication and } \\
\text { do not result in a } \\
\text { change to account } \\
\text { status }\end{array}$ & $\begin{array}{l}\text { - Education } \\
\text { - Publications (paper } \\
\text { and web) } \\
\text { - Campaigns } \\
\text { - Mass distribution of } \\
\text { different types of } \\
\text { information } \\
\text { - Instructions }\end{array}$ & $\begin{array}{l}\text { - Timing volume: partly } \\
\text { predictable } \\
\text { - Size volume: flexible, } \\
\text { can be influenced, } \\
\text { revenue body initiate } \\
\text { - Standardisation/ } \\
\text { automation: possible } \\
\text { in many cases }\end{array}$ \\
\hline Interaction & $\begin{array}{l}\text { Two-way } \\
\text { communication, } \\
\text { which in itself does } \\
\text { not result in any } \\
\text { change in account } \\
\text { status. }\end{array}$ & $\begin{array}{l}\text { - Enquiry } \\
\text { - Audit } \\
\text { - Guidance } \\
\text { - Debt collection }\end{array}$ & $\begin{array}{l}\text { - Timing volume: partly } \\
\text { predictable } \\
\text { - Size volume: flexible, } \\
\text { can be influenced } \\
\text { - Standardisation/ } \\
\text { automation: difficult }\end{array}$ \\
\hline Transaction & $\begin{array}{l}\text { Activity or services } \\
\text { that result in a } \\
\text { change in account } \\
\text { status or account } \\
\text { information. }\end{array}$ & $\begin{array}{l}\text { - Filing of tax returns, } \\
\text { VAT etc } \\
\text { - Payment/refund }\end{array}$ & $\begin{array}{l}\text { - Timing volume: very } \\
\text { predictable } \\
\text { - Size volume: can to a } \\
\text { very little degree be } \\
\text { influenced } \\
\text { - Standardisation/ } \\
\text { automation: great } \\
\text { potential }\end{array}$ \\
\hline
\end{tabular}

Source: OECD (2007)

For some time now, revenue bodies have been providing more accessible information services through use of new technology (e.g. by building on-line capability or making information available 24 hours a day, 7 days a week). More recently, many revenue bodies have given taxpayers the functionality of registering for tax system purposes, filing tax returns and paying tax electronically, all at times convenient to them. There have also been developments in the use of telephony services with revenue bodies in many countries establishing large call centre arrangements employing sophisticated telephony technology to facilitate access by phone for taxpayers to the information and other services they require (OECD, 2007, p. 32).

The spectrum of services within each category varies from country to country. Many of the revenue bodies, such as the Canadian Revenue Agency (CRA) have placed high priority over the past several years on improving its service delivery over the web. A survey by $\operatorname{OECD}(2007$, p. 30) finds that several revenue agencies are finding the e-mail channel to be a challenge. It can be more time and cost intensive than initially expected. The survey reports that unstructured e-mail poses the biggest challenge and it can take a long time to respond to such contact. One interviewee reports that users do not come with a question, they come with a problem. Hence, most revenue agencies 
do offer email as an option, but they do not promote the channel. For the user, e-mail is often seen as an alternative to a telephone call or a letter. Most citizens and businesses see e-mail as a natural part of the communication options and they will often search for an e-mail address at the website. However, the Netherlands Revenue Agency does not offer e-mail at all, and some other tax administrations have a very limited offer (OECD, 2007, p. 30).

Most revenue agencies have call centre facilities. The next step for some of them is now to transform these into contact centres, where several channels are integrated including e-mail. Overall, with a 90-95\% penetration, telephone contact will remain an important channel for revenue bodies' universal access objectives (OECD, 2007, p. 30).

Revenue Agencies are aiming for a reduction in the volume of users that are served on face-to-face basis. One of the main reasons for this is that it is known to be the most expensive channel, and therefore efforts are made to reduce volumes.

Revenue Agencies, such as the one in Singapore, are increasing serviceorientation by converting from a hard-copy filing system to a paperless imaging system, adopting the extensive use of electronic filing, a one-stop service to answer inquires about any type of tax, the ability for filers to see the entire tax form with any corrections before it is submitted, the use of interest-free installment plans for paying taxes with direct deduction from bank accounts, separate functional areas within the tax administration with little opportunity for corruption, and a changed attitude of officials toward taxpayers. During the last decade, the tax administration service of Singapore has gone from being the lowest rated government agency in public satisfaction to one that ninety percent of the taxpayers found to provide courteous, competent, and convenient services (Alm et al., 2011, p. 2). In Sweden, the assumption is that many taxpayers want to comply but that they are making mistakes unintentionally and that compliance would increase by focusing on service and information, influencing policy makers and initiating changes in the law to make it easier for users to comply (OECD, 2007, p. 42).

\subsection{Service satisfaction}

Authors believe that satisfaction is an emotional reaction, a transactionspecific measure (see Bitner, 1990; Bolton \& Drew, 1991; Cronin \& Taylor, 1992). Emotions refer to a set of responses occurring especially during consumer experience (Westbrook \& Oliver, 1991). High levels of satisfaction may include positive and negative emotions (Arnould \& Price, 1993). These emotions could motivate some to evade taxes by understating their taxable incomes and/or overstating their deductible expenses.

Gomeza, McLaughlinb and Wittinkc, (2004) identify customer satisfaction (CS) as playing a key role in a successful business strategy. Public sector service 
dimensions are somewhat different from those of the private sector as they are not threatened by the competitors and hence lacks in continuous improvement through competitive strategy. Sarin and Anil (2007) recommend that manpower in service organizations must work with the focus of satisfying the customer.

The general conceptualization of satisfaction can be grouped into two namely: transaction-specific satisfaction and cumulative satisfaction (Boulding et al., 1993; Jones \& Suh, 2000; Yi \& La, 2004). Transaction-specific satisfaction is a customer's evaluation of his or her experience and reactions to a particular service encounter (Cronin \& Taylor, 1992; Boshoff \& Gray, 2004), and cumulative satisfaction refers to the customer's overall evaluation of the consumption experience to date.

Carlzon (1989) opines that the quality of any service encounters or »moments of truth « experienced by customers forms part of their overall impression of the whole service provided (Dale, 2003) and by implication, their impression of the organization itself. Deming (1982) suggests that most people give their opinions based on the people that they see, and they are either satisfied or dissatisfied or delighted or even on the continuum in between.

According to Shand and Arnberg (1996, p. 17) different relations exit between the state and customers of the administration and include being consumers and being taxpayers. Taxpayer, customers have clear obligations towards the tax administration, but expect a certain level of service or help that would aid them in carrying out their duties.

Putnam (2000, p. 24) and Orren (1997, p. 78) also argue that public satisfaction with public trust in government is a function of both public expectation and perception of governmental performance. They identify an inverse relationship between public satisfaction and public expectation but a positive relationship between public satisfaction and public perception of governmental performance.

Public sector organizations lack a detailed understanding of the meaning of client service and its implications (Fountain, 2001, p. 65), and require knowledge about »how to improve public services (Hodgson, Farrell \& Connolly, 2007, p. 362-363). In particular, the public sector in most developing nations hardly has any performance measure of the services they provide (Kloot, 1999). This leads to public officials believing that they are largely responsible and accountable to the State rather than the people they serve (Kuppusamy et al., 2006). Although services provided are likely to be beneficial for the public, public officials however do not attract a strong package of significant satisfaction in the manner in which they meet the needs of the wider community. The lack of knowledge about interrelatedness of one department with another, method of operation, styles of negotiation and the execution of service delivery are reported to be frequent causes of public 
dissatisfaction. Dissemination of information, exchange of views and ideas, and the analysis of potential solution to cases could therefore be essential to improved satisfaction with public service delivery.

Surveys and opinion polls confirm that citizens want improvements in the ways in which governments serve them, that is, a public administration that delivers better services and extends their reach and coverage more effectively and efficiently (Rondinelli, 2007). The ultimate goal of SARS is to provide public services whose elements are internally consistent and directed at meeting the needs of a specific target market segment. Too much or too little emphasis on one component will lead to problems and poor customer perceptions. Too much emphasis on behaviour might provide of friendly and personable environment at the expense of slow, inconsistent, or chaotic service. Too much emphasis on professional judgment might lead to good solution to customer problems but also to slow, inconsistent or insensitive service (Mansor \& Razali, 2010).

\section{Research methods}

A purposive survey was carried out of the needs of 375 public sector tax practitioners in eight South African provinces, omitting Limpopo. The survey sought to determine SARS public service satisfaction, its helpfulness in tax filing compliance process, and usefulness of SARS taxpayer education and other general services. The questionnaire administered included open questions which allowed respondents to give answers in a manner suitable to them. Closed ended questions were chosen in order to produce standardized answers data that can be analysed. Forty respondents were targeted for each province. Limpopo province was surveyed last but results from this province were excluded because of the problem of logistical difficulties encountered with field workers and enumerators during the survey and the fact that funds were depleted.

Satisfaction was measured using a 7-point Linkert Scale for importance, 1 = highly satisfied, 2 = very satisfied, $3=$ somewhat satisfied, $4=$ normal, 5 = somewhat unsatisfied, 6 = very unsatisfied, 7 = highly unsatisfied. According to Cooper (2000), this type of scale is considered to be an interval scale. Therefore, measurement of central tendency and its dispersion can be made. A composite domain-specific satisfaction score was calculated by averaging the responses for the items. High scores reflected high levels of domain satisfaction; low scores indicated low levels. Responses were dichotomized as 0 (very dissatisfied, somewhat dissatisfied, neither satisfied nor dissatisfied, and somewhat satisfied) and 1 (very satisfied). Appropriate response percentages are hence presented. 


\subsection{Descriptive analysis}

Of the forty respondents targeted in each of the eight provinces covered in this survey, two returns were incomplete for each of the three provinces of Gauteng, Mpumalanga and Northern Cape. Western Cape survey was more rigorous than others because of the availability and enthusiasm of field workers and the province's economic importance. Eastern Cape, Kwazulu Natal and Gauteng have more non-citizens working as tax practitioners in the public sector. More men were surveyed in Eastern Cape, Free State, Kwazulu Natal, and Mpumalanga. More women were surveyed in Western Cape, Gauteng and North West provinces. An equal number of male and female respondents were surveyed in the Northern Cape. In order to be truly representative, our survey concentrated more on public sector tax practitioners who are Africans, Coloured and Asians.

\subsection{Professionals covered in the survey by province}

Table 2: Professionals covered in the survey by province

\begin{tabular}{|l|r|r|r|r|r|r|}
\hline Region & $\begin{array}{r}\text { Chief } \\
\text { Financial } \\
\text { Officer }\end{array}$ & $\begin{array}{r}\text { Financial } \\
\text { Officer }\end{array}$ & $\begin{array}{c}\text { Financial } \\
\text { Manager }\end{array}$ & $\begin{array}{r}\text { Account- } \\
\text { ant }\end{array}$ & Others & Total \\
\hline Eastern cape & 1 & 1 & 6 & 23 & 8 & 40 \\
\hline FS & 1 & 1 & 6 & 23 & 8 & 40 \\
\hline Gauteng & 6 & 8 & 4 & 14 & 6 & 38 \\
\hline KZN & 6 & 10 & 7 & 16 & 0 & 40 \\
\hline Mpumalanga & 6 & 8 & 4 & 14 & 6 & 38 \\
\hline NC & 3 & 7 & 9 & 10 & 8 & 38 \\
\hline North West & 1 & 1 & 6 & 23 & 8 & 40 \\
\hline Western cape & 5 & 25 & 11 & 35 & 20 & 101 \\
\hline
\end{tabular}

Source: Survey data

In general terms, most of the tax practitioners working in the public sector's finance departments are Accountants, Finance Officers/Managers. They are mainly aged between 34 and 37 having been employed in the public sector for an average of eight years.

\subsection{Employment in spheres of government by province}

They mainly work with local (37\%), provincial (29\%) and municipal (25\%) authorities. Only some $9.6 \%$ work with the national government. 
Graph 1: Sphere of government where tax practitioners operate In South Africa

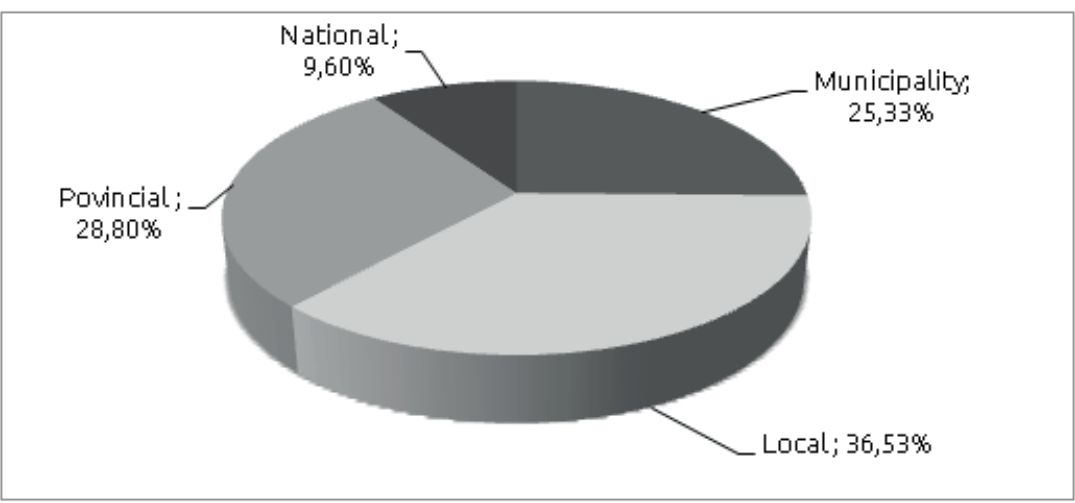

Source: Survey data

\section{Results}

\subsection{Tax practitioners opinion of the helpfulness of SARS and tax advisers}

Graph 2: Tax practitioners opinion regarding how helpful SARS and tax advisers are in completing tax returns per province (in percentages)

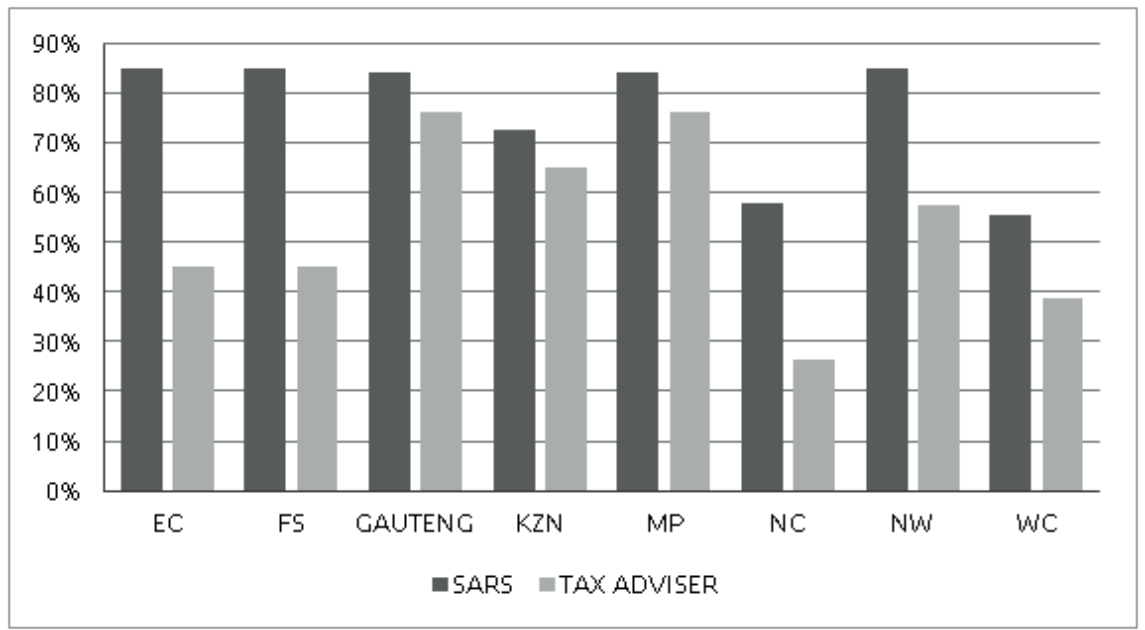

Source: Survey data

\subsubsection{SARS helpfulness in completing tax returns}

Tax practitioners assessment of SARS helpfulness in completing tax returns as compared to receiving help from other tax advisors would suggest that SARS helpfulness is highly appreciated by public sector tax practitioners. Nearly $73 \%$ of those covered in the survey believe that SARS support in completing 
tax returns is helpful. This assessment is significant and generally popular among Accountants and older tax practitioners.

\subsubsection{Tax practitioners rating of the helpfulness of tax advisors}

About $54 \%$ of those covered in the survey consider the assistance provided by the tax advisor in completing the tax returns as helpful. Tax practitioners employed as Financial Officers, Financial Managers, Accountants, older tax practitioners and those in possession of diploma and degree level education particularly appreciate the help they receive from tax advisors in completing tax returns.

\subsection{Tax practitioners satisfaction with general services provided by SARS}

\subsubsection{Respondents satisfaction with SARS taxpayer education}

About $66 \%$ of those covered in the survey believe that SARS taxpayer education is helpful. Those belonging to the Accounting profession significantly hold this view. Other tax practitioners do not feel so strongly.

Graph 3: Percentage of respondents who are satisfied with the following services provided by SARS per province

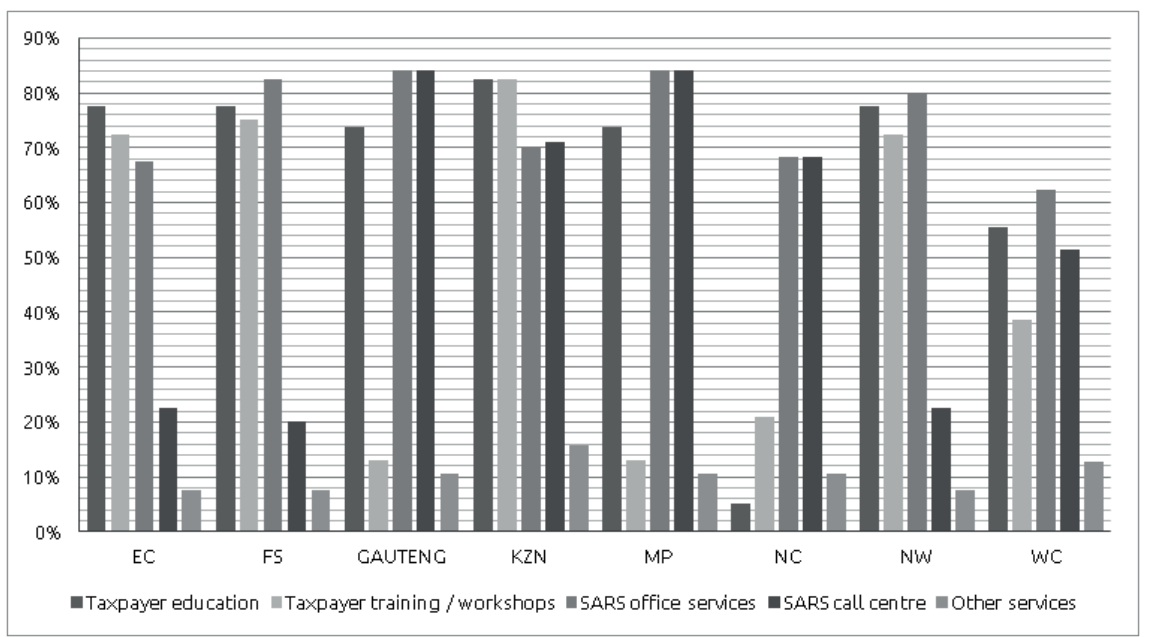

Source: Survey data

\subsubsection{Satisfaction with SARS Taxpayer training}

About $51 \%$ of the respondents consider SARS taxpayer training as useful. Tax practitioners who work as Financial Managers, Accountants, and those who possess secondary level of education, diploma, degree or have special tax education find tax payer training to be quite useful. 


\subsubsection{Respondents satisfaction with SARS Office services}

About $71 \%$ of the tax practitioners surveyed regard SARS Office services as useful. This is irrespective of their employment types or socioeconomic characteristics. Older tax practitioners are more satisfied with SARS office services.

\subsubsection{Respondents satisfaction with SARS call centre services}

In terms of SARS general services considered unhelpful, SARS call centre services rank highest.

\subsection{Public service satisfaction survey results}

\subsubsection{The time taken to pay refunds}

About $82 \%$ of tax practitioners surveyed are happy about time taken by SARS to pay refunds. This is more so for male tax practitioners and those with accounting backgrounds. Here SARS should keep up the good work.

\subsubsection{The time taken by SARS to respond to enquiries}

About $73 \%$ of those surveyed are very satisfied and provide a positive feedback about time taken by SARS to respond to enquiries.

\subsubsection{The manner in which SARS deals with enquiries}

The manner in which SARS deals with enquiries is also appreciated by tax practitioners. About $80 \%$ of respondents are happy about the manner in which SARS deals with enquiries.

\subsubsection{Personal contact with SARS office}

The majority (about 79\%) of the tax practitioners say that they have made personal contacts with SARS Offices in the past. Africans, Financial Managers, Accountants, and those with specialized tax education significantly hold this view.

\section{Conclusion}

There are complaints regarding substandard service delivery by tax practitioners to their clients in respect of advice and tax compliance representation. This has prompted the introduction of new legislation and a paradigm shift by the South Africa Revenue Service (SARS) in terms of how the organisation relates to tax practitioners and the need to embrace the profession by providing comprehensive services to them.

This study has sought to examine how satisfied public sector tax practitioners are with the services provided by SARS to enhance their tax compliance and 
their professional standing with their clients. A survey of 375 tax practitioners has been conducted across eight provinces who have been asked to rank the degree of their satisfaction with services provided by SARS. More public sector tax practitioners believe that SARS officials are more helpful in completing returns than the tax advisors.

On the other hand, more than two thirds of those surveyed, rate SARS taxpayers education, and office services, positively while only half of them have good opinion of SARS training. Accountants and those with specialised education strongly appreciate SARS taxpayer education. Public sector tax practitioners do not need much training on tax issues from SARS. Only about $20 \%$ of them indicate the need for some kind of additional quarterly training.

Overall, public sector tax practitioners have a positive attitude toward SARS general services, mainly regarding payment of refunds, responding to queries and the manner in which SARS deals with enquiries.

Professor Dr. Oludele Akinloye, AKINBOADE holds a degree of Doctor of Philosophy in Development Economics. He worked with the University of Botswana as an Economics Lecturer before joining the University of South Africa where he became a Professor and Director of the School of Economic Sciences. He is now an independent consultant.

Dr. Mandisa Putuma MOKWENA holds a doctoral degree in Economics. She was formerly the Group Executive of Segmentation and Research of South African Revenue Services, Pretoria. She was also previously an economic adviser to the Director General of the Country's National Intelligence. She is now an independent consultant. 
Are Public Sector Tax Practitioners Satisfied with the Services of South Africa Revenue Service?

\section{References}

- Alford, J. (2002). Defining the client in the public sector: A social-exchange perspective. Public Administration Review 62(3), 337-346.

- Allingham, M. G., \& Sandmo, A. (1972). Income tax evasion: A theoretical analysis. Journal of Public Economics 1(3-4), 323-38.

- Alm, J., Cherry, T., Jones, M., \& McKee, M. (2011). Taxpayer Information Assistance Services and Tax Compliance Behavior. Economics Working Paper Series, Working Paper 1101, April 2011, 1-27. Tulane University.

- Arnould, E. J., \& Price, L. L. (1993). River magic: extraordinary experience and the extended service encounter. Journal of Consumer Research 20(1), 24-45.

- Bitner, M. J., \& Hubbert, A. R. (1994). Encounter Satisfaction versus Overall Satisfaction versus Quality: The Customer's Voice. In: Rust, R. T., \& Oliver, R. L. (Eds.), Service Quality: New Directions in Theory and Practice (72-94). Thousand Oaks, CA: Sage.

- Boccabella, D. A. (1993). Legal professional privilege: the case for tax accountants' clients. Taxation in Australia, 391-397.

- Bolton, R. N., \& Drew, J.H. (1991). A Longitudinal analysis of the impact of service changes on customer attitudes. Journal of Marketing. 55(1), 1-9.

- Boshoff, C., \& Gray, B.( 2004). The Relationships Between Service Quality, Customer Satisfaction and Buying Intentions in The Private Hospital Industry. South African Journal of Business Management 35(4), 27-37.

- Boulding, W., Kalra, A., Staeling, R., \& Zeithaml, V. A. (1993). A Dynamic Process Model of Service Quality, From Expectations to Behavioral Intentions. Journal of Marketing Research 30(1), 7-27.

- Burton, M., \& Dabner, J. (2008). The partnership model of the relationship between tax administrator an tax practitioners: drivers, challenges and prospects. Journal of Australia Taxation 11(2), 108-137.

- Business Times. (1998). Long-serving civil servants still qualify for big tax breaks: Looks at recent amendments to the Income Tax Act. Retrieved 27. 02. 2009, from http://www.btimes.co.za/98/0816/btmoney/money2.htm.

- Cardona, F. (2002). Scope of Civil Services in European Countries. OECD: Paris. Retrieved 27. 02. 2009, from http://www.oecd.org/dataoecd/44/331850438. pdf.

- Carlzon, J. (1989). Moments of Truth. New York, NY: HarperCollins.

- Cooper, D. R. (2000). Business Research Method (7th ed.) New York: McGrawHill/Irwin.

- Cronin, J. J. Jr., \& Taylor, S. A.(1992). Measuring service quality: A reexamination and extension. Journal of Marketing 56(3), 55-68.

- Dale, B. G. (2003). Managing Quality. 4th Ed. Oxford: Blackwell Publishing.

- Deloitte (2006). Public Sector Briefing, Summer 2006. Retrieved 2. 3. 2009, from http://www.deloitte.com/dtt/cda/doc/content/ie_en_ PublicSectorBriefing_Aug06.pdf.

- Deming,W. E. (1982). Out of Crisis. Cambridge, MA: Massachusetts Inst. of Technology.

- Employee Benefits Research Institute. (2005). Fundamentals of Employee Benefit Programs. Part Five. Public Sector. Retrieved 27. 02. 2009, from http:// www.ebri.org/pdf/publications/books/fundamentals/Fnd05.Prt05.Chp41.pdf.

- Erard, B. (1993). Taxation with Representation- An Analysis of the Role of Tax Practitioners in Tax Compliance. Journal of Public Economics. 52(2), 163-197. 
- Evans, J. R., \& Lindsay, W. M. (2001). The Management and Control of Quality. Fifth Ed. South-Western, Thomas Learning.

- Fin24. (2012). Civil service fraud cost SA R300 million. July 23, 2012. Retrieved 14. 11. 2012, from http://www.fin24.com/Economy/Civil-service-fraud-costsSA-R3bn-20120723

- Fitzpatrick, M. (2007). Waar daar nie 'n wil is. Beeld, 9 Januarie: 11.

- Fountain, J. (2001). Paradoxes of public sector customer service. Governance: An International Journal of Policy and Administration 14(1), 55-73.

- Fox, W., \& Meyer, I. H. (1995). Policies for Public Service Transformation. Eliot Avenue: Creda Press.

- Gendron, P.-P. (2005). Value-Added Taxation of Public sector bodies and NonGovernmental Organizations: A Developing Country Perspective. Institute for International Business, University of Toronto, ITP Paper 0514, July 2005. Retrieved 21. 02. 2012, from http://www.rotman.utoronto.ca/iib/ITP0514.pdf.

- Giannoccaro, R., Costantino, N., Ludovico, A., \& Pietroforte, R. (2008). Measuring citizen satisfaction with aspects of public services from a local authority and determining their importance: A case study. Public Organization Review 8(1), 1-15.

- Gomeza, M. I., McLaughlinb, E. W., \& Wittinkc, D. R. (2004). Customer Satisfaction and Retail Sales Performance: An Empirical Investigation. Journal of Retailing 80(4), 265-278.

- Hamlyn, M. (2007). Municipalities failing to pay R794m debt to water boards. Johannesburg Star. March 20, 2007, p. 7

- Hazelhurst, E. (2003). A net gain: new legislation and better collection are building government's political credibility. Financial Mail 170(11), 64-66.

- Hite, P. A., \& McGill, G. A. (1992). An examination of taxpayers' preferences for aggressive tax advice. National Tax Journal 45(4), 389-403.

- Hodgson, L., Farrell, C., \& Connolly, M. (2007). Improving UK public services: A review of the evidence. Public Administration 85(2), 355-382.

- Howard C. (2010). Are we being served? A critical perspective on Canada's Citizens First satisfaction surveys. International Review of Administrative Science. 76(1), 65-83.

- Jackson, B. R., \& Milliron, V. C. (1986). Tax compliance research: Findings, problems, and prospects. Journal of Accounting Literature 5, 125-65.

- Jones, M. A., \& Suh, J. (2000). Transaction-specific Satisfaction and Overall Satisfaction: An Empirical Analysis. Journal of Services Marketing 14(2), 147159.

- Kaplan, E. S., Reckers, P. M. J., West, S. G., \& Boyd, J. C. (1988). An Examination of Tax Reporting Recommendations of Professional Tax Preparers. Journal of Economic Psychology 9(4), 427-443.

- Kasipillai, J., \& Jabbar, H. A. ( 2003). Tax compliance attitude and behaviour: Gender and ethnicity differences of Malaysian taxpayers. Malaysian Accountant, February 2003, 2-7.

- Kesselman, J. R. (1994). Compliance, enforcement and administrative factors in improving tax fairness. In: Maslove, A. M. (Ed.), Issues in the Taxation of the Individuals (62-84). Ontario: Queen' Printer.

- Killian, S., \& Doyle, E. (2004). Tax Aggression among Tax Professionals: The Case of South Africa. Journal of Accounting Ethics and Public Policy 4(3), 159189.

- Kirchler, E. (2007). The Economic Psychology of Tax Behaviour. Cambridge: Cambridge University Press. 
- Klein, J. (2001). How quality award-winning governments handle customer service. Journal of Organizational Excellence, Summer 2001, 41-47.

- Klepper, S., \& Nagin, D. S. (1989). The role of tax practitioners in tax compliance. Policy Sciences 22, 167-194.

- Klepper, S., Mazur, M., \& Nagin, D. (1991). Expert Intermediaries and Legal Compliance: The Case of Tax Preparers. The Journal of Law and Economics 34, 205-229.

- Kloot, L. (1999). Performance Measurement and Accountability in Victorian Local Government. The International Journal of Public Sector Management, 12(7), 565-583.

- Kumar, S. (No Date). Tax treatment of small saving instruments. Retrieved 27. 02. 2009, from http://rbidocs.rbi.org.in/rdocs/Bulletin/DOCs/24602.doc.

- Kuppusamy Singaravelloo. (2006). The Composite Performance Index for Local Authorities in Peninsular Malaysia: A Measurement. In: Proceedings of the National Conference on Public Management, 2006, December, Universiti Utara Malaysia.

- Lau, E. (2000). Government of the future. Paris: OECD.

- Lederman, L. (2007). Statutory Speed Bumps: The Roles Third Parties Play in Tax Compliance. Stanford Law Review 60(3), 695-743.

- Lee, R. (2012). SARS Focuses On Tax Practitioners' Compliance. Tax-News. com. London, Thursday, July 19. Retrieved 12. 11. 2012, from http:// www.lowtax.net/asp/story/front/SARS_Focuses_On_Tax_Practitioners Compliance 56409.html.

- Luscombe, M. (2004). Can Tax Professionals Be Creative without Being Abusive. Taxes 82(9), 3-4.

- Mansor, N., \& Razali, C. H. C. M. (2010). Customers' Satisfaction towards Counter Service of Local Authority in Terengganu, Malaysia. Asian Social Science 6(8), 197-208.

- Malcom Andrew (2012). 36 Obama aides owe \$833,000 in back taxes. Investors. Com, 26 January. Retrieved 12. 11. 2012, from http://news.investors. com/politics-andrew-malcolm/012612-599002-obama-white-house-staff-backtaxes.htm.

- Marshall, R., Smith, M., \& Armstrong, R. (2006). The Impact of Audit Risk, Materiality and Severity on Ethical Decision Making; An Analysis of the perceptions of Tax Agents in Australia. Management Audit Journal 21(5), 499.

- Murphy, R. (2012). Off-payroll tax avoidance is rife, but government does nothing. The Guardian, 5 October. Retrieved 4. 11. 2012, from http://www. guardian.co.uk/commentisfree/2012/oct/05/off-payroll-tax-avoidancegovernment.

- National Fraud Authority (UK). (2012). Annual Fraud Indicator, March 2012. Retrieved 4. 11. 2012, from http://www.homeoffice.gov.uk/publications/ agencies-public-bodies/nfa/annual-fraud-indicator/annual-fraud-indicator2012?view=Binary.

- Nienaber, S. G. (2010). Factors that could influence the ethical behaviour of tax professionals. Meditari Accountancy Research 18(1), 33-46.

- Organisation for Economic Cooperation and Development. (2007). Improving Taxpayer Service Delivery: Channel Strategy Development, Guidance Note, Forum on Tax Administration, Taxpayer Services Sub-group, May.

- O'Connor, M. (2001). Tax Preparation Services for lower income filers: a glass half full, or half empty. Tax Notes. Tax Analyst Special Report. January 2001, 231-250. 
- Orren, G. (1997). Fall from grace: The public's loss of faith in government. In: Nye, J. Jr., Zelikow, P., \& King, D. (Eds.), Why people don't trust government (77-107). Cambridge, MA: Harvard University Press.

- Paung, S. (2006). Burma's Civil Servants, Soldiers to Pay Income Tax. The IRRAWADDY. Retrieved 27. 02. 2009, from http://www.irrawaddy.org/article. php?art_id=5998.

- Pretty, I., \& Negadi, A. (2012). Tackling 'disturbing' tax evasion and avoidance. Public Service Europe. Retrieved 4. 11. 2012, from http://www. publicserviceeurope.com/article/1969/tackling-the-disturbing-problems-oftax-evasion-and-avoidance.

- Putnam, R. (2000). Bowling along: The collapse and revival of American community. New York: Simon and Schuster.

- Rakitzis, L. (2012). Greek Public and Private Sector: Corruption, Tax Evasion and Impunity Still Alive and Kicking. Keep Talking Greece, 1 August, 2012.

- Rawlings, G., \& Braithwaite, V. (2003). Voices for change: Australian perspectives on tax administration. Australian Journal of Social Issues 38(3), 263-268.

- Reinganum, J. F., \& Wilde, L. L. (1991). Equilibrium Enforcement and Compliance in the Presence of Tax Practitioners. Journal of Law Economics and Organization 7, 163-181.

- Rondinelli, D. A. (2007). Governments Serving People: The Changing Roles of Public Administration in Democratic Governance. In: Rondinelli D. A. (Ed.), Public Administration and democratic governance: Governments Serving Citizens (1-28). A United Nations Publication, Publication No.: ST/ESA/PAD/SER.E/.

- Roth, J. A., Scholz, J. T., \& Witte, A. D. (1989). Taxpayer Compliance, Volume 1: An Agenda for Research. Philadelphia, PA: University of Pennsylvania Press.

- Rousseau, Jean-Jacques (1762). The Social Contract, or Principles of Political Right, bk 1, chapter 6. Translated 1782 by G. D. H. Cole, public domain.

- Sarin Anil (2007). Contemporary Issues in Services Marketing. Prabandhan: Indian Journal of Marketing 37, 40-44.

- Sakurai, Y., \& Braithwaite, V. (2001). Taxpayers' Perceptions of the Ideal Tax Adviser: Playing Safe or Saving Dollars?. Working Paper No 5. The Australian National University. Centre of Tax System Integrity.

- Sarker, T., \& Kitamura, Y. (2006). Technical assistance in fiscal policy and tax administration in developing countries: the state of nature in Bangladesh. Tokyo: Keio University.

- Scotchmer, S. (1989). The Effect of Tax Advisors on Tax Compliance. In: Roth, J. A., \& Scholz, J. T. (Eds.), Taxpayer Compliance: Social Science Perspective (182199). University of Pennsylvania Press.

- Shand, D., \& Arnberg, M. (1996). Background Paper. In: Shand, D. (Ed.), Responsive Government; Service Quality Initiatives. Paris: OECD.

- Song, Y., \& Yarbrough, T. (1978). Tax ethics and taxpayer attitudes: a survey. Public Administration Review, 442-452.

- South Africa Revenue Service. (2003). Discussion paper: regulating tax practitioners. Pretoria: Government Printer.

- Tomasic, R., \& Pentony, B. (1991). Taxation Law Compliance and the Role of Professional Tax Advisers. Australian and New Zealand Journal of Criminology 24; 241-257.

- Westat Inc. (1980). Individual Income Tax Compliance Factors Study, Qualitative Research. February 1980. United States Internal Revenue Service. 
Are Public Sector Tax Practitioners Satisfied with the Services of South Africa Revenue Service?

- Westbrook, R. A., \& Oliver, R. L. (1991). The dimensionality of consumption emotion patterns and consumer satisfaction. Journal of Consumer Research 18, 84-91.

- Williams, C., Saunders, M., \& Staughton, R. (1999). Understanding service quality in the new public sector. The International Journal of Public Sector Management 12(4), 366-379.

- Yi, Y. J., \& La, S. N. (2004). What Influences the Relationship Between Customer Satisfaction and Repurchase Intentions? Investigating the Effect of Adjusted Expectation and Customer Loyalty. Psychology and Marketing 21(5), $351-373$. 


\section{ALI SO DAVČNI SVETOVALCI JAVNEGA SEKTORJA ZADOVOLJNI S STORITVAMI DAVČNE UPRAVE JUŽNE AFRIKE?}

Ključne besede: izpolnjevanje davčnih obveznosti, davčni svetovalci, davčna administracija, Južna Afrika

\section{Uvod}

Država Južna Afrika je po besedah ministrice za javni sektor in administracijo Lindiwe Sisulu v proračunskem letu 2009/10 izgubila 300 milijonov randov (36,6 milijona ameriških dolarjev) zaradi goljufij in drugih finančnih prekrškov javnih uslužbencev. Državne službe so izgubile 260 milijonov randov $(31,7$ milijona ameriških dolarjev), regionalne službe pa 40 milijonov randov (8,88 milijona ameriških dolarjev). Analiza izpolnjevanja davčnih obveznosti med 35.000 južnoafriškimi davčnimi svetovalci je pokazala, da so osebno Davčni upravi Južne Afrike (SARS) dolžni v znesku 260 milijonov randov (31,7 milijona ameriških dolarjev), medtem ko imajo istočasno 18.000 neplačanih vračil. Neizpolnjevanje obveznosti skladov in podjetij je tudi glavni razlog za zaskrbljenost SARS-a. Ugotovljeno je bilo, da so davčni svetovalci povezani z več kot 107.600 podjetji in skladi.

Ministrstva se soočajo s težavami pri zbiranju, shranjevanju in posredovanju informacij o davčnih prihodkih. Večina ministrstev se občasno lahko zanese samo na ročno shranjene podatke o obdavčenju, ki jih praktično nikoli ne posredujejo naprej. Davčni strokovnjaki, zaposleni v organih javnega sektorja, kot so direktorji gospodarsko-finančnega sektorja, finančni uradniki, računovodje, pomagajo ministrstvom pri izpolnjevanju davčnih obveznosti.

Vendar je veliko pritožb strank glede tega, da storitve davčnih svetovalcev pri svetovanju in prikazovanju davčnih obveznosti niso dobre. Pritožbe se večinoma nanašajo na dejstvo, da so davčne napovedi izpolnjene po nasvetu davčnih svetovalcev, ki nosijo le omejeno odgovornost za dane nasvete.

Težava je v tem, da v Južni Afriki ne obstajajo minimalni standardi glede usposobljenosti ali izkušenj, ki bi se zahtevali za davčne svetovalce za opravljanje poklica, prav tako niso vsi davčni svetovalci zavezani kodeksu profesionalnega ravnanja. Le približno 55 \% vseh davčnih svetovalcev, ki so registrirani pri SARS-u, je registriranih pri kakem strokovnem telesu, medtem ko drugi nimajo nobenega nadzora ali odgovornosti.

\section{Razlogi za razširitev storitev finančnih organov za davkoplačevalce}

Zaradi nedavnega povečanja števila javno-zasebnih partnerstev (PPP) za zagotavljanje storitev, ki jih je prej izvajal javni sektor sam, je nujno, da Davčni urad Južne Afrike spremeni svoj način sodelovanja z davčnimi svetovalci. PPP povečuje težave pri obračunavanju davka na dodano vrednost (DDV), česar se 
mora partner javnega sektorja zavedati. Tukaj naj bi bil SARS-ov izobraževalni program ključnega pomena. Partner javnega sektorja mora določiti naravo storitve, ki jo zagotavlja, osebo, ki nudi storitev, obračun DDV-ja od prihodka, osebo, ki je odgovorna za prijavo DDV-ja in odbitek DDV-ja pri vseh povezanih stroških.

Čeprav je veliko vprašanj o obračunu DDV-ja skupnih vsem organom javnega sektorja, se tisti, ki delajo na različnih področjih, srečujejo s številnimi specifičnimi vprašanji. Na primer, vsak organ javnega sektorja, ki vodi maloprodajne trgovine, podeljuje koncesije za trgovine, upravlja menze za zaposlene, zagotavlja parkirna mesta ali zagotavlja splošne, športne ali zabavne storitve za skupnost, bi moral razmisliti, ali mora obračunavati DDV. Lokalne oblasti bi npr. morale obračunavati DDV iz plačila pristojbin. pridobljenih iz oskrbe objektov za golf. Ministrstva lahko zagotovijo računalniške in internetne storitve zaposlenim. Te ne smejo biti obdavčene, če so storitve potrebne za opravljanje službenih zadolžitev, davčne obveznosti pa veljajo, če bo računalnik, ki ga je financiral delodajalec, kupil zaposleni za osebno uporabo.

V javni upravi se kot pomembna tema poudarja osredotočenost na stranke in tako si v zadnjih časih javne organizacije prizadevajo za izboljšanje storitev za stranke.

SARS je sprejel stališče, da bi se predpisi morali odzivati na realnost. Zato navezuje stik z davkoplačevalci, poudarja izobraževanje, dobre storitve za stranke in odprt dialog. SARS na tak način cilja na občutek južnoafriških davčnih svetovalcev za socialno odgovornost in krepi preprečevanje davčne utaje, medtem ko se, vsaj v začetni fazi zakonodajne interakcije, izogiba dragim kazenskim ukrepom, ki bi lahko omajali pripravljenost in motiviranost davčnih svetovalcev za upoštevanje davčne zakonodaje.

\section{Literatura o davčnih svetovalcih in zadovoljstvu z izvajanjem javnih storitev v Južni Afriki}

Objavljene raziskave o ravnanju davčnih svetovalcev na splošno in še posebej v Južni Afriki so še vedno zelo omejene. Nienaber ocenjuje literaturo glede na dejavnike, ki bi lahko vplivali na etično vedenje davčnih svetovalcev v Južni Afriki. Hazelhurst sklepa, da sta izvajanje nepregledne davčne zakonodaje in neučinkovito pobiranje davkov pred letom 1994 dopustila južnoafriškim davčnim zavezancem preusmeriti velike vsote davka od dobička v davčne olajšave in davčne oaze.

Članek obravnava zadovoljstvo s storitvami, ki jih nudi SARS davčnim svetovalcem javnega sektorja. Zajema vprašanja o povezavi med izpolnjevanjem davčnih obveznosti in obdavčitvijo, ki so pomembna za organe javnega sektorja in SARS. Poudarja pomen načina komuniciranja pri usmerjanju davčnih svetovalcev. Poudarja vlogo davčnih svetovalcev pri izpolnjevanju davčnih obveznosti. Pri tem razširja program podpore davčnih agencij davkoplačevalcem, kjer se je spremenil model odnosa davčnih oblasti 
z davkoplačevalcem in še posebej davčnim svetovalcem. Članek prav tako obravnava, kaj pomeni zadovoljstvo s storitvijo, še posebej ker se nanaša na javni organ, ki opravlja storitve za stranke, ki plačujejo davke. Raziskovalne metode in rezultati raziskave so predstavljeni v zaključku članka.

\section{Zadovoljstvo s storitvijo}

Organizacijam v javnem sektorju primanjkuje dobro razumevanje pomena storitev za stranke in njihovih posledic, potrebujejo pa znanje o tem, »kako« izboljšati javne službe. Javni sektor v večini držav v razvoju nima pravega sodila za merjenje uspešnosti storitev, ki jih ponuja. To vodi do prepričanja javnih uslužbencev, da so pristojni in odgovorni predvsem državi, ne pa ljudem, ki jim služijo.

Avtorji verjamejo, da je zadovoljstvo čustveni odziv, merjen na specifični transakciji. Čustva se nanašajo na skupino odzivov, ki se pojavijo predvsem v izkušnjah potrošnikov. Visoka stopnja zadovoljstva lahko vključuje pozitivna in negativna čustva. Ta čustva lahko nekatere motivirajo, da utajijo davke s podcenjevanjem svojih obdavčljivih prihodkov in/ali s precenitvijo svojih priznanih stroškov.

\section{Raziskovalna metoda}

Predstavljena raziskava je bila izvedena na podlagi odgovorov 375 davčnih svetovalcev javnega sektorja v osmih provincah Južne Afrike, brez province Limpopo. Raziskava je skušala določiti zadovoljstvo s SARS-ovo javno službo, njeno pripravljenost pomagati v procesu urejanja davčne usklajenosti in uporabnost SARS-ovega izobraževanja davkoplačevalcev ter druge splošne storitve. Razdeljeni vprašalnik je vključeval vprašanja odprtega in zaprtega tipa. V vsaki od devetih provinc je bilo v ciljni skupini štirideset anketirancev. Anketa je bila nazadnje izvedena v provinci Limpopo, a so bili rezultati iz te province izključeni zaradi logističnih težav z delavci na terenu in popisovalci med anketiranjem ter dejstvom, da so bila izčrpana vsa sredstva. Odgovori so bili razdeljeni na 0 (zelo nezadovoljen, nekoliko nezadovoljen, ne zadovoljen ne nezadovoljen, nekoliko zadovoljen) in 1 (zelo zadovoljen).

\section{Rezultati}

Velik del davčnih strokovnjakov javnega sektorja meni, da so pri izpolnjevanju davčnih napovedi SARS-ovi uradniki bolj v pomoč kot davčni svetovalci. Več kot dve tretjini anketiranih ocenjuje SARS-ovo izobraževanje davkoplačevalcev in administracijo pozitivno, medtem ko jih ima le polovica dobro mnenje o SARS-ovem usposabljanju. Računovodje in tisti s specialistično izobrazbo zelo cenijo SARS-ova izobraževanja davkoplačevalcev. Davčni svetovalci javnega sektorja ne potrebujejo veliko izobraževanja SARS-a o davčnih vprašanjih. Le približno 20 \% jih je izrazilo potrebo po dodatnem četrtletnem izobraževanju. Na splošno imajo davčni svetovalci javnega sektorja pozitiven odnos do SARSovih storitev, predvsem glede plačila povračil, odzivov na poizvedbe in načina, kako SARS obravnava vprašanja. 